\title{
ABEL 2
}

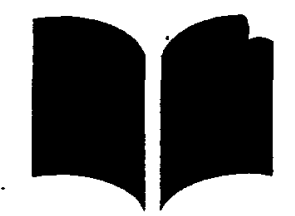

Advancing Basic

Education and Literacy

Phase 2

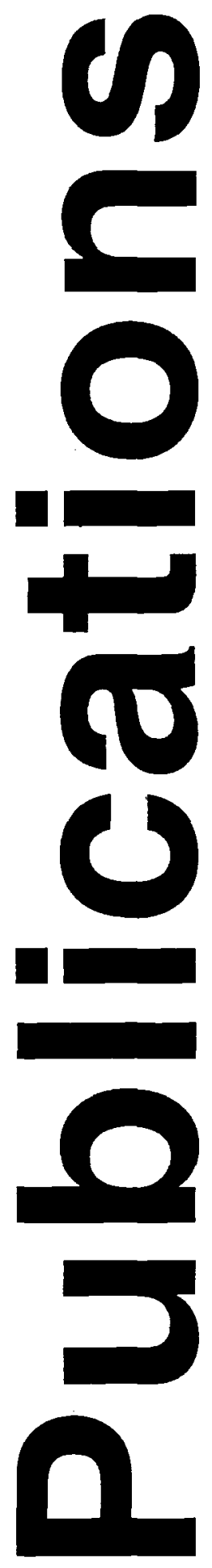

A USAID project to help countries educate citizens for democratic participation and economic growth 


\section{About the ABEL project...}

The U.S. Agency for International Development's Advancing Basic Education and Literacy project works to expand access to and improve the quality of basic education, formal education systems, early childhood education, and nonformal education for out-of-school youth and adults. With experience in over twenty countries in Africa, Asia, Latin America, and the Middle East, ABEL assists governments and USAID Missions in project design, evaluation, policy reform support, pilot projects, and applied research. ABEL also provides managerial and operational support to USAID Missions that are initiating basic education programs. Finally, ABEL provides both short and long-term technical assistance and short-term training to build capacity within education ministries and local schools. The ABEL Project concentrates on strengthening the policy reform process, increasing the participation and persistence of girls in basic education, facilitating the use of technology in education, strengthening teacher quality, and developing institutional and management capacity.

The ABEL 2 Clearinghouse disseminates project experience, research results, and lessons learned to regional networks of governments, NGOs, and donors through a series of information packages, project briefs, and project monographs.

$A B E L$ is a consortium of organizations with extensive resources and experience in strengthening education systems throughout the world. The consortium provides continuity from previous USAID projects and makes possible the sharing of experience between countries, institutions, and substantive areas. The Academy for Educational Development (AED) heads the ABEL consortium, which also includes:

- Creative Associates International, Inc. (CAII)

- Education Development Center (EDC)

- Florida State University (FSU)

- Harvard Institute for International Development (HIID)

- Research Triangle Institute (RTI).

For more information visit ABEL's Web site (www.info.usaid.gov/ economic_growth/abel2/). 


\section{About this catalog...}

As part of its effort to advocate effective education practices. ABEL tries to make information available in formats useful to education policymakers and practitioners. ABEL has produced and disseminated resource packages, publications ${ }^{\circ}$. databases, and software that make available current findings in the field of basic education, ABEL's research and field studies, and lessons learned from the project's activities. ABEL's research has been sponsored by USAID through the Global Bureau's Center for Human Capacity Development, the Africa Bureau's Office of Sustainable Development, and the Latin America and Caribbean Bureau's Office of Regional Sustainable Development.

\section{How the catalog is organized...}

Documents are organized in this catalog into the following categories:

\section{- System reform}

- Girls' education

- Learning technologies

- Classroom-level improvements

- Community participation

Alternative primary school systems

Adult literacy

Anthologies of experience

\section{How to order...}

Material may be ordered from the ABEL project free of charge using the order form on the last page of this catalogue.

Alternatively, material may be ordered directly from USAID, using the "docid" numbers provided. Publications that have not yet had docid numbers assigned are show' $n$ as $\mathbf{n} / \mathbf{a}$. Contact USAID's Clearinghouse through the Internet at www.dec.org, by e-mail at docorder@dec.cdie.org, or by phone at 703-351-4006.

"ltems listed as working papers are intended as working documents, and were written for discussion purposes or for presentation at seminars or conferences. 


\section{System reform...}

\section{Education Reform Support}

by Luis Crouch, Joseph DeStefano, and F. Jleny Healey, AED and RTI, 1997.

Volume One: Overview' and Bibliography

Volume Un: Vue générale et bibliographie

Docid: English PN-ACA-717; French n/a

Volume Two: Foundations of the Approach

Docid: PN-ACA-718

Volume Three: A Framework for Making It Happen

Docid: PN-ACA-719

Volume Four: Tools and Techniques

Docid: PN-ACA-720

Volume Five: Strategy Development and Project Design

Docld: PN-ACA-721

Volume Six: Evaluating Education Reform Support

Docld: PN-ACA-722

How can development assistance for educational reform be designed so that indigenous nongovernmental and civil society organizations work together to exert positive pressure for policy reform? Education Reform Support is a sixvolume series that creates an operational framework through which educational reform initiatives, particularly in Africa, can counterbalance political interests that can deter reform, build the capacities of diverse actors to participate in the policy process, foster the role of information in policymaking, and create networks and coalitions that support continued and productive policy dialogue. The approach aims to integrate traditional public policy analysis with policy dialogue, advocacy, awareness, and political salesmanship, and to build indigenous institutional capacity. The series is designed for development agencies and for individuals interested in helping strategic elements within a country steer events toward sustainable reforms in education, as well as for host country proponents who wish to understand and use the approach.

\section{Education Reform Support: A Framework for Scaling Up School Reform}

working paper by F. Hemy Healey and Joseph DeStefano, AEL and RTI, 1997. Docid: PN-ACC-722

This document recommends actions that could be taken to systematically implement the ERS approach in the United States. 


\section{Paths of Change: Education Reforms Under Way in Latin America and the Caribbean}

\section{Senderos de cambio: Génesis y ejecución de las reformas educativas en América Latina y el Caribe}

edited by Benjamin Alvarez H. and Mónica Ruiz-Cas(mes, AED, 1997, 1998. Docid: English n/a; Spanish PN-ACB-904

As the Latin American and Caribbean regions come under increasing pressure to enter the global economy, education has emerged as a major topic in national and regional deliberations about development. This book presents case studies from several countries that have receivecl a great deal of support for education from USAID-the Dominican Republic, El Salvaclor, Jamaica, and Paraguay. The studies of education reform efforts undertaken in the 1990s focus on the processes of implementing the reforms. A final analytical chapter identifies common factors important to the successful evolution of education reforms, including the nation's capacity for reform, characteristics of the reform, strategies for implementation, and external pressures.

\section{Evaluation and Educational Reform: Policy Options}

\section{Evaluación y reforma educativa: Opciones de política}

edited by Benjamin Álvarez H. and Mónica Ruiz-Casares, AED, 1998, 1997. Docld: Engilsh n/a; Spanish n/a

This book attempts to spur the educational reform efforts underway in Latin America and the Caribbean by looking at the different dimensions of evaluation and at resulting options for framing public and private policy. Rather than simply design a model or present ready-made formulas, its main goal is to strengthen capabilities at the country level to continually reinvent education systems as one of the basic elements of the art of governance in our information-oriented society. The book's eleven essays are organized into sections on national systems, lessons of history, teacher evaluation and professionalism, and evaluation of the organization of education.

\section{An International Curricular Perspective on Decentralization: An Introduction to its Problems, Prospects, and Evaluation}

working paper by Richard Kraft, AED, 1995.

Docid: PN-ABX-790

Ethiopia is undertaking the daunting task of decentralizing almost all aspects of its school system. This involves not only local control, but the development of newly Latinized written languages, regional and zonal curricular materials, instructional adaptations at all levels, national and regional standards, and new forms of assessment, etc. The paper begins with an introduction to the topics of 
curriculum and decentralization, followed by review of the experiences of various nations around the world with the process. Specifics on the decentralization of curriculum and instruction from various nations are dealt with, followed by recommendations based on 200 years of local control experience in the United States. Particular attention is given the development of national standards, both in the United States and in other countries.

\section{DECIDE}

by Thomas Welsh and Noel F. McGirm, HIII), 1997 (forthcoming).

Docld: $n / a$

DECIDE is a computer-based simulation game designed to sensitize players to some of the major issues involved in the implementation of decentralization.

The game opens with a crisis situation requiring a decision by the players, who represent central ministry officials. Players choose among alternative responses; the program chooses the next situation in terms of whether the players' choice moves the system toward an effective decentralization. The game is designed to be played by teams of two or three people. About two hours are required to introduce the game, work through all the situations, and conduct a debriefing. A manual is provided for the trainer.

\section{Education Automated Statistical System Toolkit (EDAssist)}

by Vivian Toro, Jolmson Sikes, and Kurt Moses, AED, 1997.

$E D^{*} \Lambda$ ssist is a Windows-based software system designed for the collection, processing, and dissemination of education data, and for the planning and management of these activities. ED*Assist provides a baseline of proven standard software and a collection of techniques, illustrative examples, and related tools, which can dramatically shorten the education data collection and reporting cycle from years to months. For more information, see the $\mathrm{Ed}^{*} \Lambda$ ssist Web site (www.aed.org/edassis/).

\section{Education Policy Simulation (EPICS): Investing in Basic Education for Development: A Decision-Making Model to Improve Access to Schooling}

by Claire Brown, Haroona Jatoi, and Christina Rawley, CAll and HIID, 1989/ 1990; updated 1998. Forthcoming in French.

Docid: Particlpant's manual PN-ABI-842; Coordinator's manual PN-ABH-839

EPICS is a dynamic computer-aided simulation created to explore the complexities of education policymaking and planning at the national level in a 
low-income country. The simulation provides a realistic enviromment in which to experience and experiment with fundamental concepts and issues in planning for educational change. The game simulates the way that relationships among factors within the education system can hinder or promote access 10 and retention in basic education. Specific attention is given to countries that are decentralizing and diversifying their education systems.

\section{Improving Capacity for Policy Analysis and Planning in Cambodia's Ministry of Education, Youth and Sports} working paper by Christopher Wheeler, Kay Calavan, and Melinda Taylor, AED, 1997.

Docid: $\mathbf{n} / \mathbf{a}$

This report analyses the current capacity of Cambodia's Ministry of Education, Youth and Sports to conduct policy analysis and planning and recommends ways of building that capacity in order to strengthen the Ministry's ability to effectively address educational issues affecting Cambodian children at the primary school level. The specific audience for further technical assistance and training is the Planning and Aid Coordination Unit; training programs will also include staff from other Ministry offices and Departments, as well as officials from provinces, districts and school clusters.

.

\section{Patterns of Public-Private Sector Collaboration in the Promotion of Non-formal Education and Training: Ghana, Senegal, and Burkina Faso}

by Peter Easton, Rosemary B. Closson, and Paul Marima, ISSU, (forthcoming).

\section{The Practical Applications of Koranic Literacy Schooling in West Africa}

by Peter Easton and Mark Peach, FSU, (forthcoming).

\section{Skill Learning for Economic Success: Strategies of West African Women for Literacy and Numeracy Acquisition and the Role of Women's Voluntary Orgarizations}

by Vandra Maseman, Mwenene Mukweso, and Chris Cappacti, FSU, (forthcoming).

\section{Widening the Circle: Enlisting the Collaboration of New Partners in African Educational Development}

by Peter Easton and Rosemary Closson, FSU, (forthcoming). 


\title{
Girls' education...
}

\section{Beyond Enrollment: A Handbook for Improving Girls' Experiences in Primary Classrooms}

\section{Après l'inscription: Comment ameliorer l'experience des filles dans les classes du primaire}

\author{
by C'hloe O'Gara and Nancy Kendall, CAll, 1996.
}

Docid: English PN-ABY-867; French PN-ACC-724

The handbook provides educators with information on how to modify classroom practices to improve gender equity and promote the retention of girls in schools. The handbook is also a resource for ideas about the common differences between girls' and boys' experiences in primary school classrooms and ways to improve classroom learning for girls by acknowledging those differences. Included in the handbook are descriptions of how educators around the world have tried to understand and improve the quality of girls' classroom experience by building up their aspirations and improving their achievement. The handbook addresses six areas that contribute to girls' classroom performance: curriculum, instruction and guidance, language and speech, management of time and space, and sexuality. The intended outcomes are positive learning experiences, expanded aspirations, increased academic and workplace achievement, and improved quality of life for women.

\section{The Economic and Social Impacts of Girls' Primary Education in Developing Countries}

by Maria Floro and Joyce Wolf, CAII, 1990.

Docld: Engilsh PN-ABJ-598; French n/a

An abundance of information exists that demonstrates the impact of girls' education on family health and infant mortality. This study explores the evidence that exists worldwide of the economic and social impacts of girls' education, particularly at the primary level. The economic dimensions considered include the impact of girls' education on women's labor force participation, employment opportunities, wage earnings, and performance in the informal sector. Social dimensions include urban/rural context, socioeconomic background, and cultural variations.

\section{Gender, Culture, and Learning}

by Eileen Kane, EDC, 1996.

\section{Docld: PN-ABY-898}

This document presents an analysis of the differences in how boys and girls learn and the implications of those differences for the design and delivery of 
classroom instruction. Overall boys and girls are more alike than different in their cognitive abilities and learning processes, although there are a few differences that appear consistently across cultures. The study draws on the literature from anthropology, psychology, and biology to present conclusions and recommendations for educators.

\section{How Educating a Girl Changes the Woman She Becomes: An Intergenerational Study in Northern Ghana}

by Joyce Wolf and Martina Odonkor, CAII, 1997.

Docid: PN-ACB-730

This document examines the lives of women in a single, extended Dogomba family to determine the impact of education upon girls during their maturation into womanhood. Life stories of the Dogomba women are assessed to establish an accurate portrayal of the setting in which they live and to ascertain whether education led to reduced fertility rates, improved child health, and increased child education. The final section of the report addresses how these changes occur by examining the several hypotheses that were developed to explain the role of education upon social reform.

\section{Educating Girls: Strategies to Increase Access, Persistence, and Achievement}

\section{L'éducation des filles: Stratégies pour accroître accès, . persistance et résultats}

by Karen Tietjen, CAII, 1991.

Docld: English PN-ABK-950; French PN-ABQ-382

This document reviews the interventions-policies, programs, and projectsthat have been implemented by governments, donors, and other institutions to increase girls' access, persistence, and achievement at the primary school level. It examines both the formal system of primary education and nontraditional, alternative approaches to reach out-of-school girls. Its goal is to identify the strategies, practices, inputs, and factors that have measurably affected the availability and accessibility of basic education to girls in developing countries.

\section{Education's Impact on Girls: Five Generations of an Indian Family}

by Joyce Wolf and Mihira Karra, 1994.

Docld: PN-ABY-992

This report presents results of a research $\mathbf{h}_{;}$study designed to contribute to understanding the relationship between girls' education and fertility, child health, and child schooling. By investigating the patterns and changes in five 
generations of an Indian fannily, the study reveals changes in attitude and practice toward educating girls and the effect of that education on decisions about marriage, health care, and number of children. An understanding what factors affect family decisions about education and enhance its effects allows educators to design and implement programs that can better achieve desired economic, health, and fertility outcomes.

\section{Exploring Incentives: Promising Strategies to Improve Girls' Participation in School}

by Cymhia Prather: with lslam Balouch. Carl Monde, Engenia Monterroso, and Taufiqur Ralman, CAll, 1996.

Docid: PN-ABY-866,

This report presents information on how incentive programs lave been used to increase girls' enrollment, attendance, and performance in primary school.

Case studies are provided for three types of incentives: scholarships, school feeding programs, and incentive packages. Each case study, which was drafted by field-based practitioners familiar with the programs, includes a brief overview of the incentive, the context in which it was (or is being) implemented, a description of the program, and a discussion of the its effectiveness, sustainability, and replicability. The report also summarizes overall trends and conclusions related to outcomes, context, and features.

\section{Early Intervention: HIVIAIDS Programs for School-Aged Youth}

by Kim Siefert, CAII, 1997.

\section{Docld: PN-ACA-818}

This report presents findings from a study aimed at identifying low-cost, community-based IIIV/AIDS awareness programs that target school-age children, in particular preadolescent and adolescent youth. The study examines the use of resources at the community level to increase awareness of and change behavior among youth. A primary objective of the study was to determine the transferability of nontraditional and community-based programs that use schools as the point of delivery. Two programs were selected for indepth review: the Morehouse/YWCA Program, a community-based outreach program in Zambia that trains at-risk, out-of-school youth to work as peer outreach workers; and the Teach English Prevent AIDS Program, a schoolbased program in Cameroon that combines instruction on HIV/AIDS prevention with the teaching of English as a second language. The paper includes a summary of factors contributing to program success, discusses the transferability and sustainability of such programs, and makes general conclusions. 
Including Girls in Basic Education: Chronology and Evolution of USAID Approaches

working paper ly Christina Rawley. CAII, 1997.

Docld: $n / a$

This paper chronicles USAID's efforts to help countries provide equal access to basic education for boys and girls. It begins with an examination of the evolution of strategies for promoting girls' education and places them within the broader historical framework of gender issues and women in development. Funding trends and basic education programs for girls are reviewed as a means to highlight USAID's continuing commitment to girls' basic education. Several subsector strategies are presented including research, teacher training, staffing and administration, curriculum development, and classroom facilities. The paper concludes with suggestions for future gender-equity programs.

\section{Making Interactive Radio Instruction Even Better for Girls: The Data, the Potential, and the Scripts}

by Andrea Bosch and Lisa Hartenberger, EDC, 1996. Forthcoming in French. Docid: PN-ABY-899

This monograph analyzes achievement data from interactive radio instruction programs around the world and offers evidence of the positive effect of IRI on student achievement. The first section discusses the potential of IRI as a tool for improving learning and examines data from several countries to see whether girls are learning more through IRI compared to girls not receiving IRI and how girls are doing relative to boys. The next section is a practical guide for IRI scriptwriters and other creators of educational materials. It examines common gender biases in existing scripts and proposes several options for making scripts more gender neutral and more beneficial for girls' learning.

\section{Learning technologies}

Interactive Radio Instruction: What It Is, How It Works, and What Is Needed to Get It On the Air

Educación por radio interactiva: ¿Qué es? ¿Cómo funciona? y ¿Qué se necesita para mantenerla en el aire?

L'enseignement interactif par la radio: Ce qu'elle est, comment elle fonctionne, et ce qu'il faut pour la mettre en ondes

by Esta de Fossard, Joao Batista Ferreira-Pinto, Carleton Corrales, and Andrea Bosch, EDC, 1993.

Docid: English PN-ABX-256; Spanish PN-ABX-257; French n/a

Interactive radio instruction, or IRI, is an educational methodology that 
actively engages learners through carefully designed audio programs on radio or cassette. This manual guides readers through the many decisions involved in using IRI, from deciding whether it is the right tool lor a particular country or community, to actually designing and producing educational progranıs.

\section{Writing for Interactive Radio Instruction}

\section{Ecrire pour l'enseignement interactif par la radio}

by Esta de Fossard, EDC, 1994

\section{Docid: PN-ABX-285}

This book provides guidelines for writing interactive scripts, with an emphasis on writing for radio. The lessons emphasize the importance of setting lessons within situations and stories that echo real life; providing opportunities for listeners to engage in both creative and critical thinking and to use real and believable characters; and to present multiple realities that allow for varying responses. The book and the sample scripts it contains demonstrate a variety of approaches that can work successfully.

\section{Making Interactive Radio Instruction Even Better for Girls: The Data, the Potential, and the Scripts}

by Andrea Bosch and Lisa Hartenberger; EDC, 1996. Forthcoming in French. Docld: PN-ABY-899

See section on girls' education for abstract.

\section{Interactive Radio Instruction: Impact, Sustainability, and Future Directions}

by Alan Dock and John Helwig, EDC and The World Bank, (forthcoming).

\section{LearnTech Case Study Series}

\section{EDC, 1994; when noied, available in Spanish}

The LearnTech Case Study Series promotes the use of learning technologies to improve educational quality, pupil access, and teaching skills. Case studies focus on the effectiveness of utilizing interactive radio instruction and other learning technologies in basic education, teacher training, and out-of-school . learning for children, youth, and adults.

Interactive Radio Instruction: Broudening the Definition Docid: PN-ABR-590

Institutionalizing Radio Science in Papua New Guinea: A Response to Teacher Demand for Interactive Radio Instruction

Docid: PN-ABW-944 
Computer-Assisted Instruction in Grenada. High-Tech Success and Sustainability Against the Odds

\section{Docid: PN-ABW-945}

Active Learning, Early Child Development and Interactive Radio Instruction:

Supporring Caregivers, Parents, and Young Children

Docld: English PN-ABW-946; Spanish PN-ABW-947

Econauts: Mission Natule Radio Drama for Environmental Education in Costa Rica

Docld: English PN-ABW-948; Spanish PN-ABW-949

Ministry, Union, the Church, and Teachers: Bolivia's Parmers in Immovation Docid: English PN-ABW-950; Spanish PN-ABW-051

The Economics of Interactive Instruction: The Case of South Africa Docld: PN-ABW-952

Changing Times in South Africa: Remodeling Imeractive Learning Docid: PN-ABW-953

Adult Basic Education in Honduras: Managing Multiple Channels

Docid: PN-ABZ-498

\section{Classroom-level improvements...}

\section{Partnership for Change: Using Computers to Improve Instruction in Jamaica's Schools}

by Errol Miller, AED, 1996.

\section{Docid: PN-ACA-862}

The introduction of computers into the Jamaican education system in the early 1990s has been one of the most revolutionary steps taken by that organization in years. This case study examines education reform in Jamaica in the primary and secondary levels, particularly in the context of the policy of partnership in education. Instead of focusing primarily on the outcomes of reform, the research probes the dynamics of the relationships between the private sector, the community, and the school, as well as the processes that propel reform.

\section{Testing to Learn...Learning to Test}

by Joanne Capper, AED, 1996.

Docld: PN-ABZ-336; Executive summary In Arabic PN-ABX-625, English PN-ABS465, French $n / a$

This book analyzes the role of examinations and assessments in relation to teaching and learning in developing countries. Addressed to education policymakers and planners, the book highlights dramatic changes occurring worldwide in the design and use of testing systems, and it discusses the 
complex interaction between testing and teaching. Based on international research and classrom experience. the book provides concrete examples of ways to measure student learning. The author offers tecluniques and guidelines for the involvement of parents, teachers, and students in the use of tests to improve educational systems.

\section{Exam Fervor and Fever: Case Studies of the Influence of Primary Leaving Examinations on Uganda Classrooms, Teachers, and Pupils}

working paper by Conrad Snyder; AED, 1997.

Docid: PN-ACA-769

This study tests the proposition that teachers change their instructional practices in desired ways in response to changes on "high-stakes" national examinations. Data on classroom practices, teaclıer attitudes, and student performance in Uganda were collected before and after major changes were introduced to the national examination given at the end of Standard 7. An analysis of the data assessed the extent to which teachers changed classroom practices in response to changes in the national examination.

\section{Teacher Development: Making an Impact}

by Helen Craig, Richard J. Kruft, and Joy du Plessis, AED and The World Bank. 1998 (forthcoming).

Docid: n/a

Teacher development should be thought of as an ongoing participatory process tied to the learning needs of children. Teacher development can make a difference to student achievement, but it depends on the type of education program and support that is put in place. Many key factors can contribute to improving a teacher's performance and hence student achievement. This paper reviews these factors, presents case studies of teacher education programs that have been effective, and makes specific recommendations for improving the quality of teaching.

\section{Can High Stakes National Testing Improve Instruction? Reexamining Conventional Wisdom}

working paper by David W. Chapman and Conrad Wesley Snyder; Jr, AED, (forthcoming).

\section{Bringing Together Health and Education for School-Aged Children}

working paper by Kera Carpenter: HIII). (forthcoming). 
A Child/Learning-Centered Vision of Education: Implications for. Education Reform

Visión de la educación centrada en el aprendizaje y el niño: Implicaciones para una reforma educativa

by F. Henry Healey, RTI. (forthcoming).

Children's Health and Nutrition as Educational Issues: A Case Study of the Ghana Partnership for Child Development's Intervention Research in the Volta Region of Ghana by James Williams and Mary Catherine Leherr, IIII), (forthcoming).

\section{Community participation...}

\section{Involving Communities: Participation in the Delivery of Education Programs}

by Andrea Rugh and Heather Bossert, CAII, 1998.

Docid: Engllsh PN-ACC-721

This monograph assesses the effectiveness of community participation in education delivery. It first reviews case documents to develop an understanding of ongoing and previously implemented community participation efforts. It then looks at the circumstances that made the incorporation of community participation appear to be an appropriate strategy and evaluates the strategies' effects in terms of conventional indicators. It considers a range of independent options to see whether involving community members leads to valued ends in. itself. The study concludes by drawing implications about the effectiveness of strategies to incorporate community participation and suggests ways to utilize these strategies in future education initiatives.

\section{Planning for Community Participation in Education}

by Joyce Wolf, Eileen Kane, and Brad Strickland, AED and CAII. 1997. Forthcoming in French.

Docid: Engllsh PN-ACA-364; French n/a

This package includes a manual and computer diskette with information presented in an interlinked fashion to assist policy and program planners to make informed decisions about community participation in education. The manual and software analyze the experience of actual programs in developing countries along three interlinked dimensions-goals, strategies, and context. 


\section{Alternative primary school systems...}

\section{Primary Education for All: Learning from the BRAC Experience - A Case Study}

by Colette Chabbon, Manzoor Ahmed, Rohini Pande, and Ainn Joshi, ALD. CAII, UNICEF, Rockefeller Fonndation, 1993.

Docid: Case study PN-ABR-068; Executive summary PN-ABQ-880

This study presents the findings of a multidonor, multiclisciplinary investigation of the Bangladesh Rural Advancement Committee's (BRAC) Non-Formal Primary Education Program. BRAC provides primary education to the most disadvantaged communities of Bangladesh and has proven successful in expanding access to those historically neglected by the formal primary education system: children-especially girls-from poor, rural, landless and near-landless families. The study begins with a description of BRAC and the economic, educational, and social context in which this NGO began the nonformal primary education program. The study provides detailed descriptions of BRAC's program elements, lists issues to consider for program improvement and expansion, and analyzes the implications of the program relevant to the global Education for All community.

\section{An Update on BRAC's Non-Formal Primary Education Program}

working paper by Ame T. Sweetser, AED, 1998 (forthcoming).

Docld: $n / a$

This two-part paper updates the 1993 case study, assessing what has changed in the BRAC program since the last study and drawing lessons about education development from the BRAC model.

El aporte de Fe y Alegría a la educación primaria en América Latina: un studio comparativo longitudinal de la educación primaria impartido por Fe y Alégria y las escuelas públicas en nueve países en América Latina

by Joln Swope and Marcela Latorre. Centro de Investigación y Desarvollo de la Educación (CIDE) and PREAL (Programa de Promocion de la Reforma Educativa en América Latina y el Caribe), 1998. (forthcoming).

Fey Alegria (Faith and Joy) is an educational movement founded by the Jesuits 
in 1954. It offers a range of services to underserved populations in twelve Latin American countries, and its basic education system of over 500 schools has long been acknowledged to offer schooling that is more eflicient and costs the state less per student than does the public system. This study examines how tic 1. Alegria achieves these efficiencies through its fundamental principles of administrative decentralization, school autonomy, parent and community participation, and strong emphasis on pupil retention. $\Lambda$ s an alternative system, rather than a random set of innovations, tie y Alegric oflers many useful lessons to countries undertaking serious. and comprehensive education reforms.

\section{Adult literacy...}

\section{Adult Literacy Programs: Design, Implementation, and Evaluation}

by John Comings, Cristine Smith, and Chij Shrestha, Worl Echucation, 1995. Docld: PN-ABX-789

The study identifies the elements and processes needed to carry out a successful adult literacy program. The report reviews the merits of adult literacy, summarizes the history of literacy programs, and provides guidelines for the design of literacy programs. The.guidelines could also be used as a framework for evaluating existing efforts. The study addresses issues that include cost and financing, evaluation, management information systems, and research and development. These issues are illustrated through a case study of programs in Nepal.

\section{An Analysis of the Impact of Literacy on Women's Empowerment in Nepal}

by Shirley A. Burchfield, HIID, 1997.

\section{Docld: PN-ACA-770}

This monograph presents findings from a study of the effect on women's empowerment of two types of non-formal education (NFE) programs-basic literacy (six-month courses) and post-literacy (six-month plus three-month courses). Responses of women who had attended either type of literacy program were compared to those of women in control villages who had not attended a NFE literacy course or primary school and were not literate. Indicators of respondents' retention, use of literacy skills, and indicators of empowerment were examined. Also examined was the cost-efficiency of sixmonth versus three-month post-literacy courses. The survey was conducted approximately one year after the women had completed the courses to ascertain the degree to which the courses had lasting effects on women who completed them. 


\section{Adult Education in Asia and the Pacific: Policies, Issues, and Trends}

norking paper by lorecia (Kaifa) Roland, Al:D, 1997.

Docid: PN-ACA-768

One of the most profound problems lacing govermments throughout the Asiapacilic region is how to respond to the educational needs of almost one billion adults who missed the opportunity to attend school or dropped out early. This report surveys the range of approaches that governments in the Asia-Pacific region have developed for providing basic aclult education, including program development, audiences, outreach, funding, and constraints. The report found several positive trends in adult education in the $\Lambda$ sia-Pacific region. First, countries have made notable progress in extending basic titeracy to previously underserved adult populations. Second, countries are demonstrating new sophistication in addressing vocational and other life needs of learners within basic literacy training. Third, countries are increasingly recognizing the need to provide continuing education opportunities that reinforce and ensure the retention of basic literacy. Finally, countries are making increasing use of technology in delivering adult education.

\section{Non-Formal Education in Ecuador: Twenty Years Later Educación no formal en Ecuador: 20 años después}

\section{by Enrique Tasiguano, AED, (forthcoming).}

\section{Docld: $\mathbf{n} / \mathbf{a}$}

This paper examines what has occurred in Ecuador in the years since USAID's Non-Formal Education Project of Ecuador ended in 1976, and whether the project had any lasting effects. The paper asks how rural Ecuadorians now create, promote, assess, and lead the development of education and how they struggle to make the education system more democratic. The report focuses on the education of the communities themselves, with the external suport of agents and resources. The paper concludes that the project indeed has had long-lasting effects: official government education programs (educational materials and radio programming) continue to reflect ideas inculcated by the project; community leadership and the development of civil society has been enhanced; and other organizations have effectively applied the techniques of NFE.

\section{Anthologies of experience...}

\section{ABEL 2 Clearinghouse Information Packages}

The $A B E L 2$ Information Packages contain collcctions of materials from worldwide literature that report project experience, research, and strategies for 
education improvement. The packages provicle a range of perspeetives on important educational issues in the following areas:

\section{Early Childhood Education}

Educating Girls and Women

Educational Quality

Grade Repetition/Antomatic Promotion

Improving the Quality of Teachers

meractive Radio Instruction

Inter-Sectoral Impact of Education

Mobilizing Community Support for Education

Policy Reform

\section{ABEL 2 Resource Packages}

The ABEL 2 Resource Packages present key policy issues and best practices from successful prograns the United States. The resource packages are designed to promote policy discussion about practical approaches for improving education through private and public-sector linkages. Lach resource package includes a reader's guide and overview essay, examples of successful private and public-sector education partnerships, selected readings, and a list of further resources.

Education Practices in a Changing Economy

Education Practices and New Technologies

Gender Equity

Community and Family Parmerships for Child Development

\section{USAID Human Capacity Development for the 21st Century: Reaping the Results of Investment and Experience- Workshop Proceedings}

AED, 1997.

Docid: PN-ACC-723

This document provides a summary of the USAID I luman Capacity Development Conference held in July 1997 in Washington, DC. The proceedings summarize the dialogue that occurred on prevailing issues in educational development, highlight key ideas raised from participants, and present lessons learned from those active within this community. Themes include educational reform, higher education and partnership, basic education, training and workforce development, information technology, girls' education, and programming for gender and ethnic equity in education. 


\section{Order Form}

Name

Address

City, State/Province

Postal Codle

Country

Telephone

Fax

E-mail

Please list the titles you are orlering and language (if applicable)

1.

2.

3.

4.

5.

Mail order form to: ABEL 2 Clearinghouse

Academy for Educational Development

1875 Connecticut Avenue, NW, Suite 900

Washington DC 20009-1202

USA

USAID

For further information contact $A B E L$ at:

Telephone: 202-884-8288

Fax: 202-884-8408

E-mail: abel@aed.org

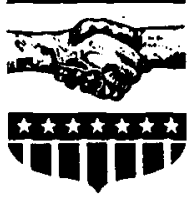

